\title{
Hepatic capillariasis in two captive Callithrix penicillata
}

\section{Capilariose hepática em dois Callithrix penicillata de cativeiro}

\author{
Washington Luiz Assunção PEREIRA ${ }^{1}$; Raimundo Nonato Moraes BENIGNO²; Klena Sarges Marruaz da \\ SILVA ${ }^{3}$; Marcella Katheryne Marques BERNAL ${ }^{1}$; Lucien Roberta Valente Miranda de AGUIRRA ${ }^{1}$

\footnotetext{
${ }^{1}$ Universidade Federal Rural da Amazônia, Instituto da Saúde e Produção Animal, Laboratório de Patologia Animal, Belém - PA, Brazil ${ }^{2}$ Universidade Federal Rural da Amazônia, Instituto da Saúde e Produção Animal, Laboratório de Parasitologia Veterinária, Belém - PA, Brazil

${ }^{3}$ Instituto Evandro Chagas, Belém - PA, Brazil
}

\begin{abstract}
This study aimed to describe the occurrence of hepatic capillariasis in two non-human primates of the species Callithrix penicillata that were kept in captivity. Case 1 was in a young female, whose liver presented pale coloring, softening due to autolysis and several noticeably whitish areas. Case 2 was in a male of unknown age, whose liver was slightly pale and brownish. Histological analysis on the samples revealed extensive interstitial fibrosis with hemosiderotic areas. Adult nematodes of Capillaria hepatica and numerous eggs, morphologically characterized by their non-embryonic ellipsoid shape, with bipolar plugs that did not protrude from the shell, thick and birefringent, with a porous layer, thus giving a striated appearance to the eggs. Some cystic formations presented nematode eggs surrounded by numerous foreign-body giant cells. The literature consulted made little reference to reports of Capillaria hepatica in non-human primates. However, similar infections have been extensively studied in domestic rodents.
\end{abstract}

Keywords: Capillariasis. Capillaria hepatica. Callithrix penicillata. Hepatopathy.

\section{Resumo}

O presente trabalho relata a ocorrência de dois casos de capilariose hepática em primatas não-humanos da espécie Callithrix penicilatta mantidos em cativeiro. O caso 1 era uma fêmea jovem, que exibiu fígado de cor pálida, suavizada devido a autólise e algumas áreas múltiplas visivelmente esbranquiçadas. $\mathrm{O}$ caso 2 foi registrado em um macho adulto, de idade desconhecida, com fígado levemente pálido e acastanhado. A análise histológica das amostras revelou extensa fibrose intersticial com áreas de hemossiderose, exemplares de Capillaria hepatica adultos e numerosos ovos morfologicamente caracterizados pela sua forma elipsóide, não-embrionárias, com tampões bipolares que se sobressaem da casca, que é espessa, birrefringente e com uma camada porosa, dando uma aparência estriada ao ovo. Algumas formações císticas continham ovos do nematóide cercados por numerosas células gigantes do tipo corpo estranho. A literatura consultada possui poucas referências acerca da presença de Capillaria hepatica em primatas não-humanos. No entanto, infecções semelhantes são bem estudadas em roedores domésticos.

Palavras-chave: Capilariose. Capillaria hepatica. Callithrix penicilatta. Hepatopatia.

Correspondence to:

Washington Luiz Assunção Pereira

Universidade Federal Rural da Amazônia, Laboratório de

Patologia Animal

Avenida Perimetral, 2501

CEP 66077-830, Belém, Pará, Brazil

e-mail: wkarton@terra.com.br

Received: 28/01/2016

Approved: 21/10/2016

\section{Introduction}

The Callitrichidae are small Neotropical primates and, according to Santos et al. (2014), the genus Callithrix has six species distributed in Brazil. Callithrix penicillata, commonly known as mico-estrela or sagui in Portuguese and blackpencilled marmoset, black-tufted marmoset, or 
black-tufted-ear marmoset in English live in regions of Cerrado and Caatinga vegetation. Vilela and Faria (2004) reported that the feeding behavior of this species is very diverse, including foraging for fruits, invertebrates (insects, spiders and snails, among others), small vertebrates and tree gum.

In situ, these animals live in social groups of 3 to 15 individuals, composed mainly of familial members (DECANINI; MACEDO, 2008); in captivity, when they are maintained for research purposes, the animals are kept in small social groups with one adult male, few adult females and juvenile individuals. Familiar care of infants is characteristic of this species.

Callitrichidae have been maintained in captivity for biomedical research for decades. Particularly, Callithrix penicillata is widely used in biomedical research, mainly in neuroscience research (TORRES et al., 2010). These species are maintained in biomedical research facilities in outdoor or indoor cages, so the health status of the primates depends on the type of cages, once the incidence of vectors and other microbiological agents are restrained through the sanitary barriers.

Capillaria hepatica, (syn. Calodium hepaticum; Hepaticola hepatica) is a nematode of the family Trichocephalidae (CALLE, 1961). This parasite is in the hepatic parenchyma and the eggs remain in this organ until they are released by the host feces, which is generally a carnivore (GALVÃO, 1981).

According to Calle (1961), C. hepatica has been found in rats, mice, dogs, hamsters, rabbits, monkeys, squirrels, pigs, cats and other animals, with rare occurrence in man. Infection by $C$. hepatica was also described in fish by Roganovic-
Zafirova et al. (2003), in which it produced alterations to the bile ducts.

This parasite was described in non-human primates by Graczyk et al. (1999), who examined 19 gorillas found dead in Volcanoes National Park, Rwanda, and observed that ten animals presented hepatic nematodiasis due to $C$. hepatica. The parasite's eggs were found in the liver of four gorillas (three juveniles and one adult) and transverse sections through the nematode were found in one young gorilla. Another six adult gorillas had areas of periportal and subcapsular fibrosis with calcified eggs

The aim of the present study is to report the presence of infection by $C$. hepatica in Neotropical primates, a form of parasitism to which little reference can be found in the specialized literature.

\section{Material and Methods}

Occurrence of hepatic capillariasis was recorded at the Brazilian National Primate Center (Health Surveillance Department of the Ministry of Health), affecting two animals of the species $C$. penicillata. Both animals were kept in indoor system cages for breeding non-human primates of the family Callitrichidae. The cases were recorded during routine anatomopathological examinations on different species of non-human primates that were necropsied in the Pathology Sector.

Tissue samples were fixed in 10\% buffered formalin solution, embedded in paraffin, sectioned at a thickness of $5 \mu \mathrm{m}$ and stained using hematoxylin-eosin for analysis. Gömöri's trichrome staining was also used in order to evaluate the extent of tissue fibrosis.

In the liver samples, twenty eggs in the lesioned areas were sagittally cut for analysis and measured 
under an optical microscope with a gridded eyepiece lens, at a magnification of $40 x$.

\section{Results}

Case 1 occurred in a juvenile $C$. penicillata female, born in captivity, which died due to a condition of generalized infection that occurred after amputation of the anterior left limb due to fracturing accompanied by extensive laceration caused by another animal. At the necroscopic examination, the liver was pale, softened due to autolysis and noticeably whitish in some parietal and visceral areas.

Histologically, the liver presented extensive interstitial fibrosis with areas of hemosiderosis. Numerous eggs were identified: these were morphologically characterized by their non- embryonic ellipsoid shape, with bipolar plugs that did not protrude from the shell, which was thick and birefringent, with a porous layer, thus giving a striated appearance to the egg. Some cystic formations presented nematode eggs and were surrounded by numerous foreign-body giant cells.

In some foci of more recent lesions, eosinophilic cells and lymphocytes were observed. Additionally, various adult forms of the Capillaria hepatica were present in the hepatic interstitium (Figure 1A), along with calcified dead parasites and foreign-body reaction with surrounding giant cells. From Gömöri's trichrome staining, a notable degree of fibrosis could be seen, with mature connective tissue (Figure 1B).

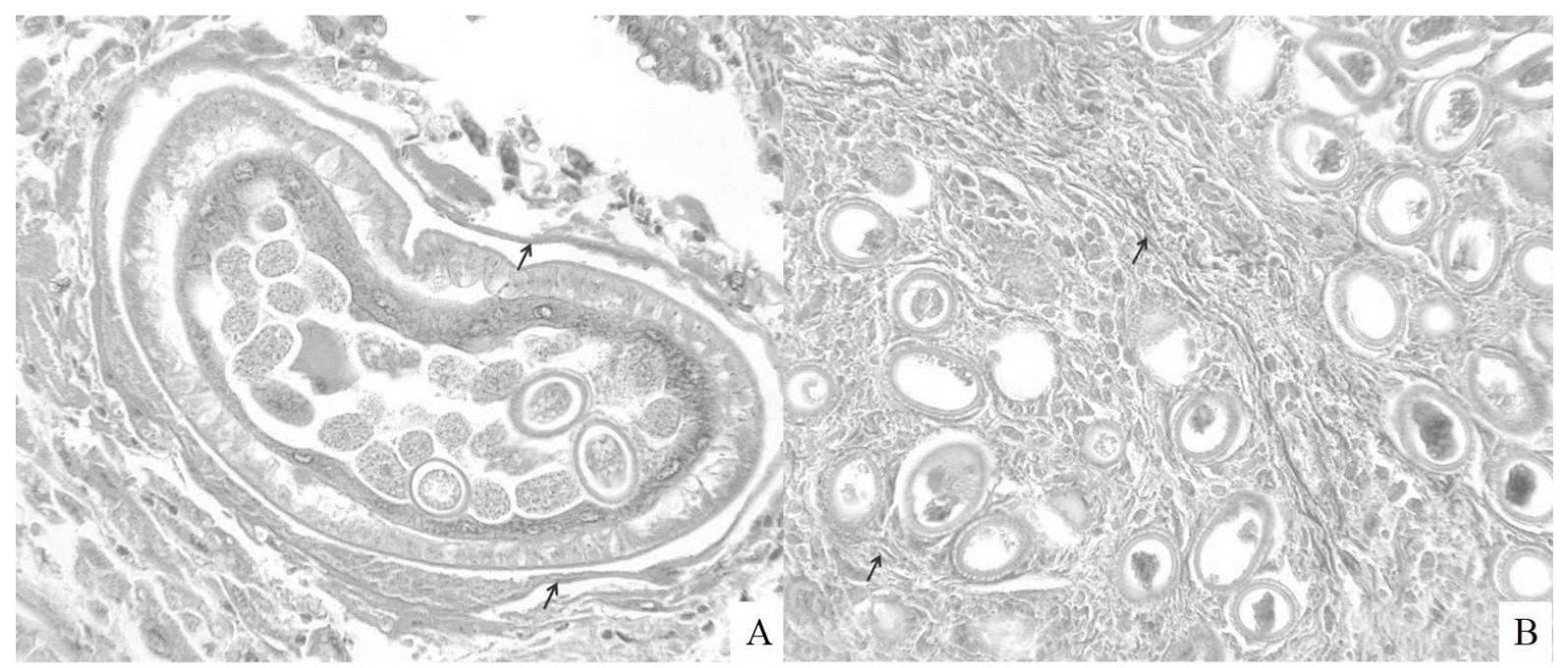

Figure 1 - A) Longitudinal section through an adult C. hepatica, surrounded by cysts (arrows), in the liver. HE. 400x. B) Loss of hepatic tissue with replacement by connective tissue (arrows). Gömöri's trichrome. 400x

The alterations present in the hepatocytes included autolysis, fat metamorphosis (+) and, in some instances, pigment compatible with lipofuscin. Another section showed cytoplasmic accumulation of bilirubin in some hepatocytes.
Case 2 occurred in an adult male of the same species, with a history of non-regenerative anemia. The animal died after treatment for anemia and inanition. At necropsy, general debilitation was observed, with emaciation and 
cachexia. Macroscopically, the liver was slightly pale and brownish. At histopathological examination, this organ presented multiple extensive coalescent areas of fibrosis in the parenchyma and large-volume infiltration of lymphocytes and macrophages. Eggs with appearance similar to those in case 1 were present, many engulfed by giant cells. Kupffer cells and hepatocytes showed hemosiderin pigment $(+++)$. There was no cholestasis.

The eggs presented an ellipsoid shape, with bipolar plugs that did not protrude from the shell. The shell wall was thick and its external layer showed small pores, thus giving the wall a striated appearance. The mean morphometric values with standard deviation were $51.8 \pm 0.8 \mu \mathrm{m}$ in length and $29.4 \pm 0.5 \mu \mathrm{m}$ in width at the largest diameters.

\section{Discussion}

C. hepatica performs mechanical action (through pressure and obstruction); irritative (toxic and antigenic) action, due to the metabolic products of secretion and excretion; and spoliation (histiocytosis and phagocytosis). This results in accentuated fibrosis, with occurrences of fatal cases in man (FERREIRA; ANDRADE, 1993).

Ruas et al. (2003) stated that the parasite is located in the hepatic parenchyma and that its eggs remain in this organ until they are released by a carnivorous predator, such as cats or dogs. With regard to epidemiology, suitable environmental conditions are fundamental for parasitism to develop. The parasitic cycle starts with the ingestion of materials that contain embryonated eggs. The infective eggs hatch in the cecum, releasing larvae that migrate via the portal vein to the liver and other tissues. Larvae take about four weeks to mature into adults and mate (SOARES et al., 2011; CDC, 2012).

Transmission of Capillaria to humans may occur through ingestion of vegetables and the livers of parasitized animals (SANTOS et al., 1985). The spread of infectious forms of Capillaria hepatica in human populations is directly related to cultural habits of consumption of the wild animals (SOARES et al., 2011). Synanthropic animals are very important factors and implicated in the cycle of transmission because they live in the urban environment. Since biomedical animal facilities are usually located in urban regions, this makes transmission among laboratory animals easier. The cases in specimens of $C$. penicillata reported here suggest that infection may have originated through ingestion of green vegetables and/or legumes that were offered to the animals within their diet. According to reports from a technical expert at the National Primate Center, it was even possible that there may have been direct contact with rats and geckos. Presence of rats in the breeding areas would give rise to release of large numbers of eggs into the environment and would lead to contamination of susceptible hosts in order to complete the parasite's circle, as explained by Ruas et al. (2003). Also, small geckos are hosts for the parasite and may be eaten by small species of primates, as C. penicilatta (WILSON, 2003).

The macroscopic characteristics described at the necropsies were similar to those reported by Ruas et al. (2003) among wild carnivores in the state of Rio Grande do Sul, Brazil. They stated that the parasitized animals presented multifocal hepatic lesions, characterized by yellow dots 
distributed randomly on the surface of the organ and on the cut surface.

The eggs of $C$. hepatica measured between 54 and $64 \mu \mathrm{m}$ in length by between 29 and $33 \mu \mathrm{m}$ in width. They were bioperculate and tray-shaped and could be identified in non-embryonic form (RUAS et al., 2003). According to these authors, the diagnosis of parasitism by $C$. hepatica in animals may be based on the presence of longitudinal and transverse sections through adult parasites and/or of the typical eggs that are found scattered through the hepatic parenchyma. In this way, the morphometric data on the eggs are compatible with those reported for nonhuman primates by Graczyk et al. (1999) and Pizzi et al. (2008).

Capillariasis consists of a granulomatous process that, as stated by Gomes et al. (2006), can occur in any area of the hepatic parenchyma and contains the parasites and their eggs. Chronic inflammatory lesions with lymphocytes, plasma cells and macrophages develop, along with reactions by the fibrous connective tissue. These features were identified in the histopathological results from the infection seen in the specimens of C. penicillata.
Histologically, in the present study, the cases of infection showed lesion patterns similar to those observed by Ruas et al. (2003) in wild carnivores in Rio Grande do Sul and Quadros et al. (2009) in 2 specimens of Puma concolor. These authors described accentuated lesions and the presence of several clusters of eggs, along with transverse and longitudinal sections through adult parasites, some surrounded by mononuclear and eosinophilic inflammatory infiltrate, with marked proliferation of fibroblasts and some foci of calcification. In the cases studied by Graczyk et al. (1999) and Soares et al. (2011), the inflammatory reaction surrounding the eggs was of mild grade.

Considering that the cases described here were recorded in primates that had been kept in external visitation cages, the infection was possibly acquired through contact with animals that could be reservoirs or disseminators for nematode eggs. In this context, Graczyk et al. (1999) emphasized that control over hepatic capillariasis in mountain gorillas should be focused on eradication or control over the populations of rats, which maintain the reservoir of $C$. hepatica in habitats shared by gorillas and humans. 


\section{References}

CALLE, S. Parasitism by Capillaria hepatica. Pediatrics, v. 27, n. 4, p. 648-655, 1961.

CENTRAL FOR DISEASE CONTROL AND PREVENION (CDC). Biology - life cycle of Capillaria hepatica. 2012. Available from: <http://bit.ly/2lEafsN>. Viewed: 15 Sept. 2016.

DECANINI, D. P.; MACEDO, R. H. Sociality in Callithrix penicillata: I. Intragroup male profile. International Journal of Primatology, v. 29, p. 433-447, 2008. doi: http://dx.doi.org/10.1007/s10764-007-9173-1.

FERREIRA, L. A.; ANDRADE, Z. A. Capillaria hepatica: a cause of septal fibrosis of the liver. Memórias do Instituto Oswaldo Cruz, v. 88, n. 3, p. 441-447, 1993. doi: 10.1590/S0074-02761993000300015.

GALVÃO, V. A. Estudos sobre Capillaria hepatica: uma avaliação do seu papel patogênico para o homem. Memórias do Instituto Oswaldo Cruz, v. 76, n. 4, p. 415433, 1981. doi: 10.1590/S0074-02761981000400010.

GOMES, A. T.; CUNHA, L. M.; BASTOS, C. G.; MEDRADO, B. F.; ASSIS, B. C. A.; ANDRADE, Z. A. Capillaria hepatica in rats: focal parasitic hepatic lesions and septal fibrosis run independent courses. Memórias do Instituto Oswaldo Cruz, v. 101, n. 8, p. 895-898, 2006. doi: 10.1590/S0074-02762006000800012.

GRACZYK, T. K.; LOWENSTINE, L. J.; CRANFIELD, M. R. Capillaria hepatica (Nematoda) infections in humanhabituated mountain gorillas (Gorilla gorilla beringei) of the Parc National de Volcans, Rwanda. The Journal of Parasitology, v. 85, n. 6, p. 1168-1170, 1999. doi: $10.2307 / 3285682$.

PIZZI, R. GORDON, J. C.; FLACH, E. J.; ROUTH, A. D.; CLARK, B.; BOARDMAN, W. S. J. Capillaria hepatica (syn Calodium hepaticum) in primates in a zoological collection in the UK. Veterinary Record, v. 163, n. 23, p. 690-691, 2008. doi: 10.1136/vr.163.23.690.

QUADROS, R. M.; PILATI, C.; MARQUES, S. M. T.; MAZZOLLI, M.; BENEDET, R. C. Capillaria hepatica in Puma concolor first report in Brazil. Journal of Zoo and Wildlife Medicine, v. 40, n. 3, p. 586-587, 2009. doi: 10.1638/2008-0194.1.

ROGANOVIC-ZAFIROVA, D. R.; JORDANOVA, M.; PANOV, S.; VELKOVA-JORDANOVSKA, L. Hepatic capillariasis in the Mediterranean barbel (Barbus meridionalis Petenyi Heck.) from Lake Ohrid. Folia Veterinaria, v. 47, n. 1, p. 35-37, 2003.

RUAS, J. L.; SOARES, M. P.; FARIAS, N. A. R.; BRUM, J. G. W. Infecção por Capillaria hepatica em carnívoros silvestres (Lycalopex gymnocercus e Cerdocyon thous) na região sul do Rio Grande do Sul. Arquivo Instituto Biológico, v. 70, n. 2, p. 127-130, 2003.

SANTOS, R. V.; COIMBRA JUNIOR, A. E. A.; OTT, A. M. T. Estudos epidemiológicos entre grupos indígenas de Rondônia. III. Parasitoses intestinais nas populações dos vales dos rios Guaporé e Mamoré. Cadernos de Saúde Pública, v. 1, n. 4, p. 467-477, 1985. doi: 10.1590/S0102311X1985000400007.

SANTOS, M. N.; DUARTE, M. H. L.; YOUNG, R. J. Behavioural and ecological aspects of black tufted-ear marmosets, Callithrix penicillata (Geoffroy, 1812) (Primates: Callitrichidae) in a semi-urban environment. Revista de Etologia, v. 13, n. 1, p. 37-46, 2014.

SOARES, M. C. P.; NUNES, H. M.; SILVEIRA, F. A. A.; ALVES, M. M.; SOUZA, A. J. S. Capillaria hepatica (Bancroft, 1893) (Nematoda) entre populações indígenas e mamíferos silvestres no noroeste do estado do Mato Grosso, Brasil, 2000. Revista Pan-Amazônica de Saúde, v. 2, n. 3, p. 35-40, 2011. doi: 10.5123/S2176-62232011000300005.

TORRES, L. B.; ARAUJO, B. H. S.; CASTRO, P. H. G.; CABRAL, F. R.; MARRUAZ, K. S.; SILVA ARAUJO, M.; SILVA, S. G.; MUNIZ, J. A. P.; CAVALHEIRO, E. A. The use of new world primates for biomedical research: an overview of the last four decades. American Journal of Primatology, v. 72, n. 12, p. 1055-1061, 2010. doi: 10.1002/ajp.20864.

VILELA, S. L.; FARIA, D. S. Seasonality of the activity pattern of Callithrix penicillata (Primates, Callitrichidae) in the cerrado (scrub savanna vegetation). Brazilian Journal of Biology, v. 64, n. 2, p. 363-370, 2004. doi: 10.1590/S151969842004000200023.

WILSON, B. The Lizard. In: BALLARD, B.; CHEEK, R. Exotic animal medicine for veterinary technician. Iowa: Blackwell, 2003. p. 31-80. 